\title{
DERIVING A RESEARCH AGENDA FOR A FINANCIAL SERVICE INDUSTRY'S METHODOLOGY FOR CARRYING OUT BUSINESS PROCESS RE-ENGINEERING
}

\author{
I.A. Kader $^{1^{*}}$ \& B. Dwolatzky ${ }^{2}$
}

\section{ARTICLE INFO}

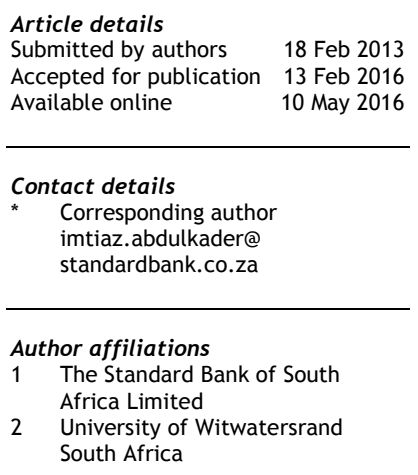

\section{DOI}

http://dx.doi.org/10.7166/27-1-592

\section{ABSTRACT}

Why do projects fail? This is a question that has been researched across various project disciplines, including that of Business Process Re-engineering (BPR). This paper introduces a different angle on why BPR projects fail. An analysis of a case study conducted within a financial institution revealed new factors that could influence BPR project outcomes, but that have not been identified in the literature. The Organisation Ring of Influence model was developed to indicate the impact that organisation behaviours and structures had on the outcome of an executed BPR project. This model also helps to highlight which factors were more influential than others.

\section{OPSOMMING}

Waarom misluk projekte? Dit is 'n vraag wat oor verskeie projekdissiplines nagevors is, insluitende dié van besigheidsprosesherontwerp. Hierdie artikel stel 'n nuwe hoek bekend om die oorsaak vir projekmislukking te bepaal. 'n Analise van 'n gevallestudie, wat by 'n finansiële instansie geloods is, het nuwe faktore wat die besigheidsprosesherontwerp beïnvloed, onthul. Hierdie faktore is nie in bestaande navorsing geïdentifiseer nie. Die Organisasie-Ring-van-Invloed model is ontwikkel om die impak wat die organisatoriesegedrag en -strukture op die eindresultaat van 'n voltooide besigheidsprosesherontwerp projek gehad het, aan te dui. Die model help ook om die faktore wat meer invloed uitoefen uit te lig.

\section{INTRODUCTION}

A Google search on the words 'latest percentage of failed projects' will yield more than $41,900,000$ results. Failure percentages of projects, ranging from 62 per cent to 68 per cent, are prevalent across various blogs and journal articles. Why have these projects failed? Surely, if you follow a set and proven method of executing a project that is associated with many successes, such high failure rates should not occur? The hard truth, however, is that these failed projects do exist - and the percentage of failures exceeds the percentages of success.

These project failures occur across various disciplines, including that of Business Process Reengineering (BPR). A range of literature has been focused on the failure of these types of projects and the factors that influence their success, such as culture, executive sponsorship and buy-in, suitable deployment teams, and organisation adaptability $[3,6,8,20]$. If so much has gone into understanding why business process improvement-type projects either succeed or fail, why do a huge number of them still fail? [20]

This paper offers a view on why these types of projects fail. It aims to answer the following two questions by conducting a case study on BPR projects that are executed within a financial institution: 
Has the literature uncovered all the factors that could positively or negatively influence the outcome of an executed BPR project?

Before describing the approach that was used in answering the above two questions, it is important to clarify what the literature defines as 'failed' or 'successful' BPR projects.

Failed projects are regarded in this paper as projects that did not successfully deliver all scoped functionality and requirements, projects that were completed later than planned, projects that went over budget, or a combination thereof. Failed projects will be further classified as those projects that have been cancelled prior to completion, irrespective of the reason for cancellation, and/or projects that have not realised the benefits stated within their business cases.

Success, on the other hand, refers in this paper to delivering the BPR project on time, on budget, with the agreed scope, and realising the business case benefits.

For this study, five projects in a financial institution were selected as case study units of analysis. These projects were analysed against influential factors derived from the literature. Further to this, a cross-case analysis was undertaken using the Fuzzy Qualitative Comparative Analysis technique (fsQCA), which was developed by Ragin [23].

The reason for selecting the setting of a financial institution was the fact that the major banks of South Africa have been recently observed as aggressively pursuing cost savings by introducing BPR initiatives. Methodologies that have been adopted as silver bullets, such as Six Sigma and Lean Engineering, were not yielding the anticipated results [7]. Examples of this can be seen in organisations such as Motorola and General Electric, who achieved or exceeded their desired benefits $[2,17]$. This context provided a perfect setting in which a case study could be conducted.

The next section provides an analysis of the existing literature.

\section{LITERATURE ANALYSIS}

A famous quote known to the BPR fraternity is as follows:

"Reengineering is the fundamental re-thinking and radical redesign of business processes to achieve dramatic improvements in critical, contemporary measures of performance such as cost, quality, service- and speed" [16].

This suggests that change should not be driven by what we know of how we do things, but by how we should be doing things that we know - that is, being normative rather than descriptive. From this quote, one can assume that business process change is driven by an organisation's purpose and capability, which are aligned to the organisation's strategy, structures, and operating models, and further directed by outside influences such as customer requirements and legislation. These elements are factors that can potentially influence the outcome of a BPR project. The literature review for this study therefore focused on recent research that looked at the focus of BPR projects and the factors identified as those that influenced the outcome of an executed BPR project.

Figure 1 summarises the key literature on BPR project executions that was engaged with for this study. It highlights the positive outcomes of the research conducted in each paper, as well as the gaps in these papers that need further research.

This summary highlights that excellent research has been conducted on the mechanics of business process re-engineering and design, particularly with regard to the availability of step-by-step guidelines for conducting analysis and modelling of to-be solutions, by means of various tools and proposed notations $[13,15,19,20]$. Major research has also been conducted on understanding the success and failure factors associated with BPR project implementations [7,15,22]. Table 1 summarises the factors that were extracted from the reviewed papers.

Taking the information synthesised from the literature review, five BRP projects that were executed within a financial institution were analysed against these factors. The results of this analysis are presented in the following section. 


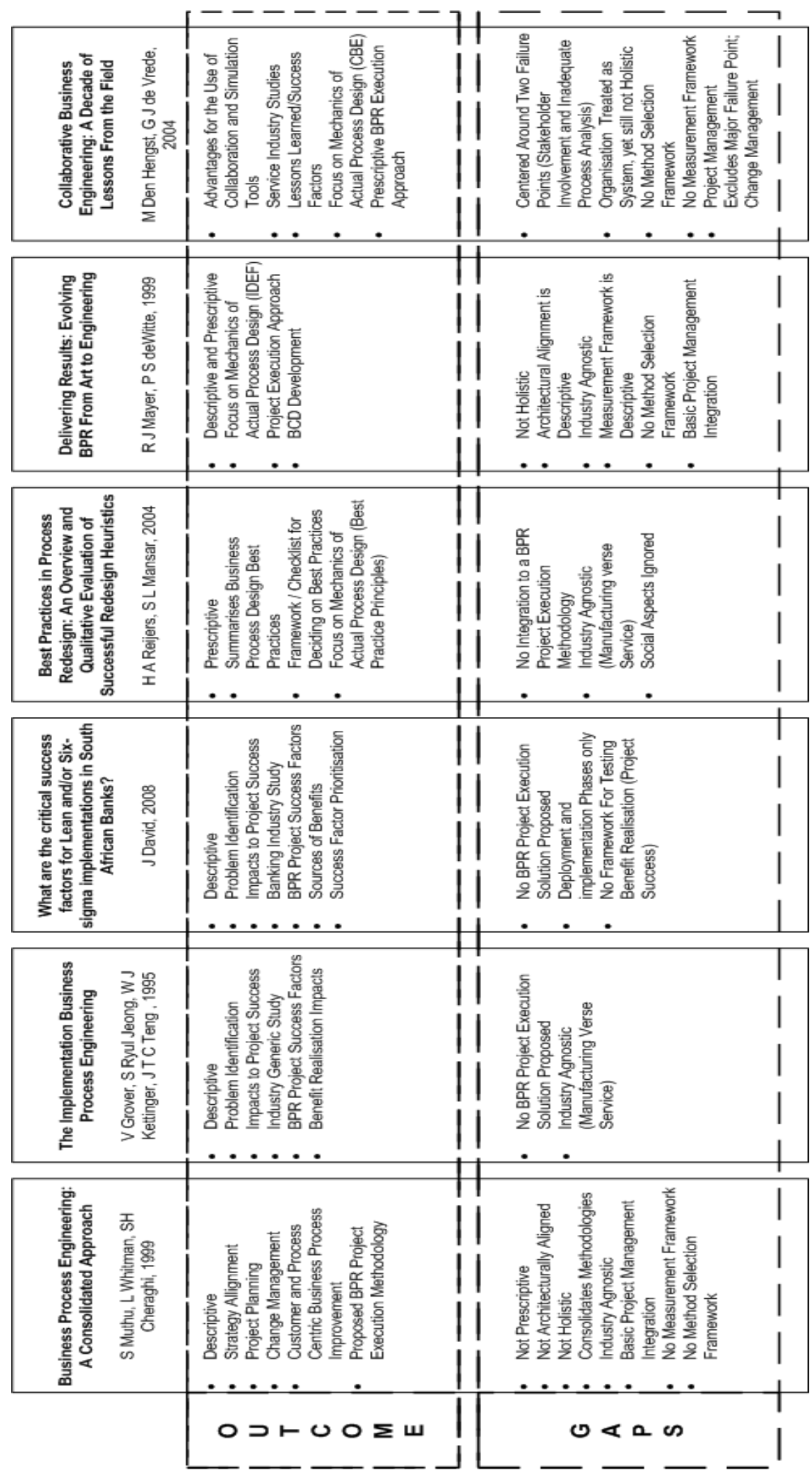

Figure 1: Gap analysis of previous research 
Table 1: Influential factors derived from the literature

\begin{tabular}{|c|c|}
\hline \multicolumn{2}{|c|}{ Influencing factors identified in the literature } \\
\hline 1. & Resistance to change \\
\hline 2. & BPR philosophy not aligned to situation \\
\hline 3. & Poor stakeholder involvement \\
\hline 4. & Poor analysis of as-is processes \\
\hline 5. & Poor design of to-be processes \\
\hline 6. & Reluctance to invest in large BPR type projects \\
\hline 7. & Alignment of vision and goals \\
\hline 8. & Business Process Management \\
\hline 9. & Continuous improvement philosophy alignment to organisation strategy \\
\hline 10. & Correct benefit calculations - quantitative versus qualitative \\
\hline 11. & Communication \\
\hline 12. & Training of all affected stakeholders \\
\hline 13. & Motivation for all affected stakeholders \\
\hline 14. & Change management \\
\hline 15. & Team structure and engagement \\
\hline 16. & Aligned human resource policies \\
\hline 17. & Customer-centric process design \\
\hline 18. & Project management \\
\hline 19. & Project priority \\
\hline 20. & Standardisation of re-engineered products inclusive of processes \\
\hline 21. & Executive sponsorship and active project participation \\
\hline 22. & Compelling business case for change \\
\hline 23. & Use of a proven process improvement methodology \\
\hline 24. & Line management ownership \\
\hline 25. & IT awareness and understanding (Business process integration) \\
\hline 26. & Stable scope of work \\
\hline 27. & Radical versus incremental business process changes \\
\hline 28. & Project benefit expectations \\
\hline 29. & Project implementation time frame \\
\hline
\end{tabular}

\section{3}

CASE STUDY ANALYSIS RESULTS

Ten months were spent conducting the case study within a financial institution in order to gain practical insight into BPR project management and execution. The case study was based on observing five BPR-type projects through their journey of execution.

\subsection{Case study unit of analysis}

The next few paragraphs provide a brief overview of the five projects that formed part of the case study.

The first project was based on re-engineering the head office client/customer service operations for the corporate sector of the bank. This included strategy alignment, Target Operating Model (TOM) definition and rollout, and the redesign of roles and responsibilities, which included job descriptions and key performance indicators. All of these would have been outcomes of the reengineering of over 360 identified processes.

The second project was similar to the first, although it differed in the type of operations serviced within the bank, as well as the number of processes. This project was also presumed to be the most complex of the five projects. It was based on re-engineering the payment operations of the business and corporate sector of the bank, and included approximately 160 identified processes.

The third project formed part of a larger programme that focused on the re-engineering of the offshore credit books with the aim of integrating them with the head office operations. This involved only design and recommendations with regard to business processes, without any confirmed implementations.

The fourth project, which was a spin-off from the first, focused on identical requirements, but differed in locality and concentrated on the organisation's international business units. 
The fifth project formed part of a larger transformational programme that looked at changing the Information Technology (IT) landscape, as well as the associated business operational processes.

The units of analysis - the above BPR-type projects - were analysed against the success factors identified in the literature $[3,7,15,22]$, as presented in Table 1 . This mapping revealed the emergence of new factors that have not been identified in the existing literature.

Table 2: Mapping of case study research findings against findings in the literature

\begin{tabular}{|c|c|}
\hline Influencing factors identified from the case study & $\begin{array}{l}\text { Influencing factors identified in the } \\
\text { literature }\end{array}$ \\
\hline Resistance to change & Resistance to change \\
\hline \multirow[t]{4}{*}{ BPR philosophy not aligned to situation } & BPR philosophy not aligned to situation \\
\hline & Poor stakeholder involvement \\
\hline & Poor analysis of as-is processes \\
\hline & Poor design of to-be processes \\
\hline Reluctance to invest in large BPR type projects & $\begin{array}{l}\text { Reluctance to invest in large BPR-type } \\
\text { projects }\end{array}$ \\
\hline Alignment of vision and goals & Alignment of vision and goals \\
\hline Business Process Management & Business Process Management \\
\hline $\begin{array}{l}\text { Continuous improvement philosophy alignment to organisation } \\
\text { strategy }\end{array}$ & $\begin{array}{l}\text { Continuous improvement philosophy } \\
\text { alignment to organisation strategy }\end{array}$ \\
\hline \multirow[t]{3}{*}{ Correct benefit calculations - Quantitative versus qualitative } & $\begin{array}{l}\text { Correct benefit calculations - Quantitative } \\
\text { versus qualitative }\end{array}$ \\
\hline & Communication \\
\hline & Training of all affected stakeholders \\
\hline Motivation for all affected stakeholders & Motivation for all affected stakeholders \\
\hline Change management & Change management \\
\hline Team structure and engagement & Team structure and engagement \\
\hline \multirow[t]{2}{*}{ Aligned human resource policies } & Aligned human resource policies \\
\hline & Customer-centric process design \\
\hline Project management & Project management \\
\hline \multirow[t]{2}{*}{ Project priority } & Project priority \\
\hline & $\begin{array}{l}\text { Standardisation of re-engineered products } \\
\text { inclusive of processes }\end{array}$ \\
\hline Executive sponsorship and active project participation & $\begin{array}{l}\text { Executive sponsorship and active project } \\
\text { participation }\end{array}$ \\
\hline \multirow[t]{2}{*}{ Compelling business case for change } & Compelling business case for change \\
\hline & $\begin{array}{l}\text { Use of a proven process improvement } \\
\text { methodology }\end{array}$ \\
\hline \multirow[t]{2}{*}{ Line management ownership } & Line management ownership \\
\hline & $\begin{array}{l}\text { IT awareness and understanding (Business } \\
\text { process integration) }\end{array}$ \\
\hline Stable scope of work & Stable scope of work \\
\hline Radical versus incremental business process changes & $\begin{array}{l}\text { Radical versus incremental business } \\
\text { process changes }\end{array}$ \\
\hline Project benefit expectations & Project benefit expectations \\
\hline Project implementation time frame & Project implementation time frame \\
\hline \multicolumn{2}{|l|}{ Organisation management structure } \\
\hline \multicolumn{2}{|l|}{ Organisation functions / Operations structure } \\
\hline \multicolumn{2}{|l|}{$\begin{array}{l}\text { Single point of accountability and decision-making (inherent } \\
\text { within organisation management structures) }\end{array}$} \\
\hline \multicolumn{2}{|l|}{ Organisation/Business politics } \\
\hline Change adoption rate & \\
\hline
\end{tabular}

Table 2 illustrates the mapping based on case study observations and success factors identified in the literature. These success factors are called 'influencing factors' in this study because, it is argued, these factors influence the outcome of the project. The factors are listed in no particular order of importance, although the last five factors under the case study section were discovered during the case study observations. As part of the case study, the analysis revealed that certain elements found within the organisation structures and culture have an influence on the BPR project's outcome. 
The next step was to focus on the cross-case analysis, which aimed to uncover and understand which factors are more influential than others.

\subsection{Cross-case study analysis}

As mentioned previously, the fsQCA technique was used to conduct the cross-case study analysis. The nature of the technique required that the factors be categorised into types of influential factors in order to derive valuable insights. The technique itself stems from set theory, and revolves around creating a truth table that is then analysed with the aim of understanding set coincidence scores and conjunctural causation [23].

The set coincidence score reveals whether a category of influential factors belonged in a set that influenced a successful project or a failed project outcome. This assisted in claims made of a particular category; if present, it would most likely influence a particular project outcome. Conjunctural causation revealed which combination of factors would need to be present in order for a particular project outcome to be realised.

The following categories of influential factors, presented in Table 3, were derived against the backdrop of the case study units of analysis outcomes as presented in Table 2 . The factors were also restated in a positive way, meaning that each factor is linked to a successful project outcome. This was important for the cross-case analysis, as it focused on understanding a set of successful projects and their associated linked factors as attributed by the case study unit of analysis results. Six categories were derived:

- $\quad$ Project Management (PM)

- $\quad$ Change Management (CM)

- Information Technology (IT)

- Management Support (MS)

- Organisation Behaviour (OB)

- Organisation Structure (OS)

Table 3: Categorisation of the influential factors

\begin{tabular}{|c|c|}
\hline $\begin{array}{l}\text { Factor } \\
\text { category }\end{array}$ & BPR project success factor \\
\hline PM & BPR philosophy between the project and organisation is aligned \\
\hline PM & Analysis of as-is processes is of good quality \\
\hline PM & Design of to-be processes is of good quality \\
\hline PM & Project outcomes are aligned with the organisation's vision and goals \\
\hline PM & The project benefit calculations are realistic and undisputed \\
\hline PM & Project has a defined team structure with strong engagement and cohesion \\
\hline PM & $\begin{array}{l}\text { Project deliverables and outcomes are aligned with Human Resource's policies } \\
\text { within the organisation }\end{array}$ \\
\hline PM & Project process design is customer-centric \\
\hline PM & $\begin{array}{l}\text { Project is independently managed by an experienced Project Manager using an } \\
\text { industry-accepted project management methodology }\end{array}$ \\
\hline PM & Project is prioritised according to organisation strategy and value outcomes \\
\hline PM & Project standardises re-engineered products and processes \\
\hline PM & Project has an undisputed and compelling business case for change \\
\hline PM & Project uses a proven process improvement methodology \\
\hline PM & $\begin{array}{l}\text { Project has an approved scope of work that is stable and/or managed according to } \\
\text { proper change control processes }\end{array}$ \\
\hline PM & Project benefit expectations are undisputed and measurable \\
\hline
\end{tabular}


Table 4: Categorisation of the influential factors (cont.)

\begin{tabular}{|c|c|}
\hline $\begin{array}{l}\text { Factor } \\
\text { category }\end{array}$ & BPR project success factor \\
\hline PM & $\begin{array}{l}\text { Project implementation time frame is realistic and planned-for, based on approved } \\
\text { scope }\end{array}$ \\
\hline CM & No resistance to changes being introduced by the project \\
\hline CM & Project has a detailed stakeholder mapping and engagement plan in place \\
\hline CM & Project has an excellent communication strategy and it is executed accordingly \\
\hline CM & Project identifies and trains all affected stakeholders \\
\hline CM & Project deliverables and outcomes motivated all affected stakeholders \\
\hline CM & Project has a detailed change management strategy and it is executed accordingly \\
\hline MS & Executive sponsorship exists, and the executive sponsor actively participates \\
\hline MS & Line management ownership of project delivery is prevalent \\
\hline IT & $\begin{array}{l}\text { Project team has strong IT awareness and IT understanding when considering } \\
\text { business process integration into the IT system landscape }\end{array}$ \\
\hline OS & Organisation has a formal Business Process Management structure in place \\
\hline OS & Organisation has a management structure that supports project execution \\
\hline OS & $\begin{array}{l}\text { Organisation's functions/operations structure is stable during the execution of the } \\
\text { project }\end{array}$ \\
\hline OS & $\begin{array}{l}\text { Single point of accountability and decision-making is applied on the project } \\
\text { (inherent within organisation's management structures) }\end{array}$ \\
\hline OS & Executive sponsor for the project remains stable \\
\hline OS & Organisation has stable, standardised tools for business process analysis and design \\
\hline OS & Organisation has a strong relationship with the delivery partner/vendor \\
\hline $\mathrm{OB}$ & Organisation is eager to invest in large BPR-type projects \\
\hline $\mathrm{OB}$ & $\begin{array}{l}\text { Organisation has a continuous improvement philosophy that aligns with the } \\
\text { organisation's strategy }\end{array}$ \\
\hline $\mathrm{OB}$ & $\begin{array}{l}\text { Selected BPR approach is aligned to the organisation's acceptance of change (radical } \\
\text { or incremental) }\end{array}$ \\
\hline $\mathrm{OB}$ & Organisational/Business politics do not influence decisions made on the project \\
\hline OB & Organisation has a high change adoption rate \\
\hline
\end{tabular}

After applying the fsQCA analysis technique, the following results emerged:

- The presence of the 'Organisation Behaviour' factor, in combination with the 'Organisation Structure' factor, would most likely result in a successful BPR project being executed.

- The relative importance of the factor categories compared with each other, as presented in Table 4.

Using the above information, the Organisation Ring of Influence (ORol) was developed. The aim of the model is to highlight the importance of organisational behaviours and structures in relation to the influence they have on executing successful BPR projects. 
Table 5: Relative importance of each category of influential factors

\begin{tabular}{|c|l|c|}
\hline $\begin{array}{c}\text { Category of } \\
\text { influential } \\
\text { factors }\end{array}$ & \multicolumn{1}{|c|}{ Relative importance } & $\begin{array}{c}\text { Set } \\
\text { coincidence } \\
\text { value }\end{array}$ \\
\hline OS & Core condition of high importance & 0.54 \\
\hline OB & Core condition of high importance & 0.54 \\
\hline PM & $\begin{array}{l}\text { Complementary condition of medium } \\
\text { importance }\end{array}$ & 0.53 \\
\hline CM & $\begin{array}{l}\text { Complementary condition of medium } \\
\text { importance }\end{array}$ & 0.47 \\
\hline IT & $\begin{array}{l}\text { Complementary condition of low } \\
\text { importance }\end{array}$ & 0.5 \\
\hline MS & $\begin{array}{l}\text { Complementary condition of low } \\
\text { importance }\end{array}$ & 0.31 \\
\hline
\end{tabular}

\subsection{Organisation Ring of Influence (ORol)}

The Organisation Ring of Influence (ORol) is depicted in Figure 2, and covers the influential categories of 'Organisation Behaviour' and 'Organisation Structure'. The model is centred on the influence of organisation structures and culture on the outcome of a BPR project.

'Organisation/Business Politics', which is an element of 'Organisation Culture', is defined as "the pursuit of individual agendas and self interest in an organisation without regard to their effect on the organisation's efforts to achieve its goals" [9]. From this definition, it is easy to see how this behaviour, which forms part of the organisation's culture, can influence the outcome of a BPR project.

'Change Adoption Rate', another element of 'Organisation Culture', is not to be confused with 'Resistance to Change'. The latter is concerned with the deliberate and conscious decision of affected stakeholders not to accept any organisational change too readily. 'Change Adoption Rate', which can be influenced by resistance to change, concerns the ability of an organisation in terms of the period taken before any change is implemented and standardised within the organisation.

'Business Function Structure', an element of 'Organisation Structure', influences the success of a BPR project due to the value chain process philosophy. Process value chains can start in the 'Product Design' department and end in the 'Sales' department, which results in multiple process owners, disparate understanding of process, and disparate continuous improvement projects [1]. This phenomenon can result in re-engineering parts of a single value chain through different teams and different executive sponsors, without understanding the impact of the holistic nature of the value chain itself [1]. All parts of a process, if isolated and re-engineered, could result in the value chain being left worse off than it was before [1].

Organisation structure also determines 'Management' structures - a difficult one to understand in terms if how it influences the success of a BPR project. During the case study, it was observed that a matrix-type management structure can support a BPR project by having many senior stakeholders focused on a single goal, while on the other hand it could also negatively impact a BPR project by having many senior stakeholders with different goals trying to influence the direction of the project. Matrix management also adds many points of accountability and decisionmaking, and this was found to impact the payments project negatively.

The ORol model contains elements that are brought into the project simply as part of its inheritance, because the project was being executed within the organisation. As noted in the literature analysis of previous research, these elements are not considered as part of the execution of BPR projects, even though they could be considered the most influential factors in the outcome of a BPR project. These factors should, however, be considered whenever a BPR project is planned for execution. How this should be done is something that can be considered in future work. 


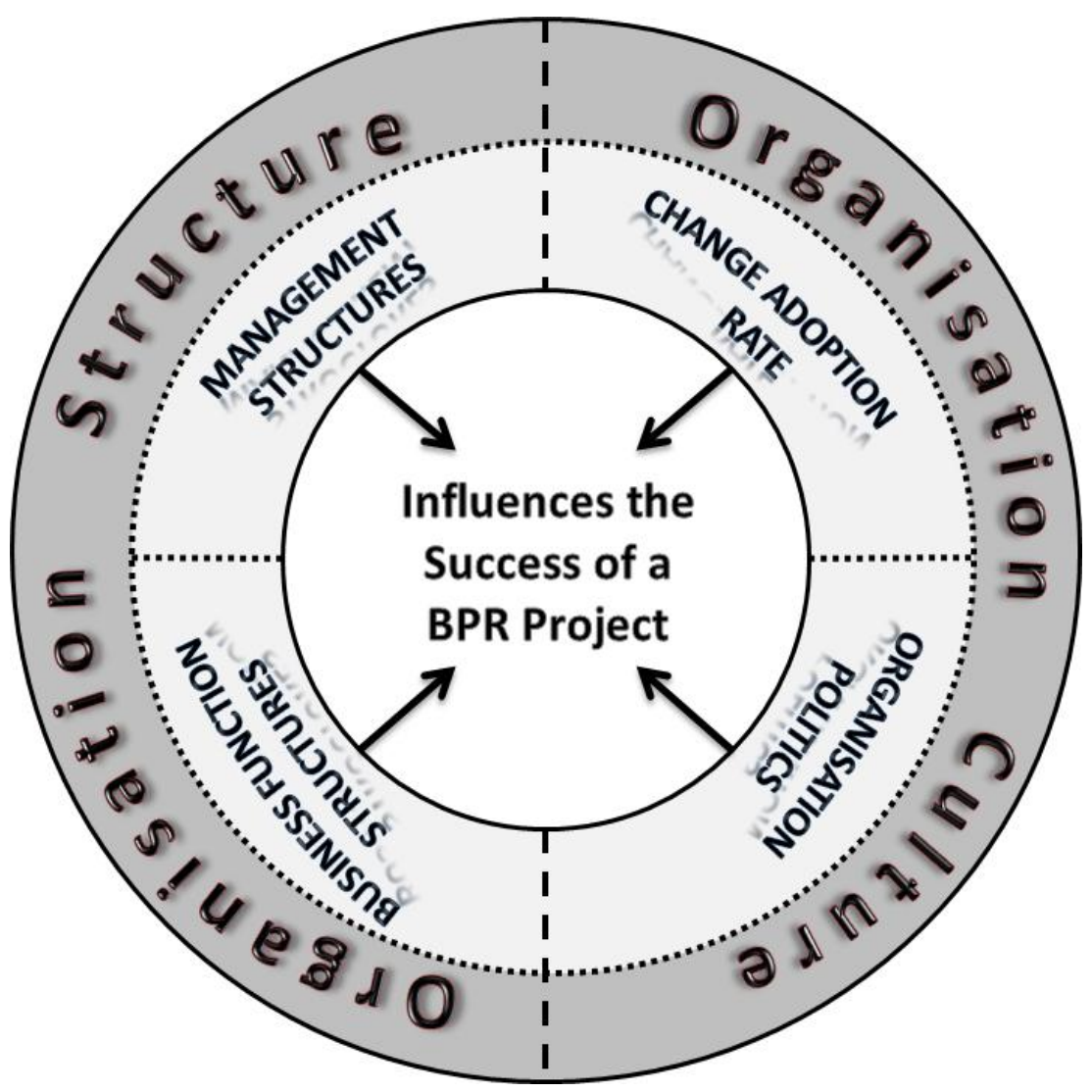

Figure 2: Organisation Ring of Influence (OROI)

\section{4}

\section{CONCLUSION}

This study revealed that the literature did not cover all the factors that might influence a BPR project's outcome. By conducting a case study on five BPR-type projects over a period of ten months, the following factors were considered to be newly-identified factors that were influential in the success or failure of a BPR project:

- $\quad$ Organisation management structure that supports project execution;

- Organisation functions/operations structure remains stable during the execution of a project;

- $\quad$ Single point of accountability and decision-making is applied to the project (inherent within organisation management structures);

- $\quad$ Executive sponsor for the project remains stable;

- Organisation has a strong relationship with its delivery partner/vendor;

- Organisation/business politics do not influence decisions made on a project; and

- Organisation has a high change adoption rate.

From further analysis conducted during the case study and by applying the fsQCA technique, the relative importance of the various influential factors was revealed. It was found that the 'Organisation Behaviour' and 'Organisation Structure' factors were most influential on the outcome of a BPR project. This culminated in the ORol model, which was developed in order to explain the importance and influence that these types of factors have on the outcome of a BPR project.

The results of this research indicate areas for future consideration. For example, there is a need to understand better how one could approach the creation of understanding within an organisation about which influential factors are present in a positive or negative format. Furthermore, how should an organisation prioritise the mitigation of the identified negative influential factors? 


\section{REFERENCES}

[1] Ackoff, D.R. 1995. Systems based improvement with Russell Ackoff. Retrieved from: http://www.systemswiki.org/index.php?title=Systems_Based_Improvement_with_Russell_Ackoff. Accessed on 23 March 2012.

[2] Process Quality Associates. 2006. Six sigma: The evolution of six sigma. Retrieved from: http: / / www.pqa.net/ProdServices/sixsigma/W06002009.html. Accessed on 15 March 2012.

[3] BPR Learning Online Centre. 1999. Reengineering success factors. Retrieved from: http: //www.prosci.com/factors.htm. Accessed on 14 March 2012.

[4] Checkland, P. 1999. Systems thinking, systems practice: Includes a 30 year retrospective. West Sussex: John Wiley and Sons, Ltd.

[5] Cresswell, J.W. 2009. Research design: Qualitative, quantitative and mixed methods approaches. $3^{\text {rd }}$ edition, California: Sage.

[6] Davenport, T.H. 2007. The fad that forgot people. Retrieved from: http: / /www.fastcompany.com/magazine/01/reengin.html. Accessed on 14 March 2012.

[7] David, J. 2008. What are the critical success factors for lean and/or six-sigma implementations in South African banks? University of South Africa.

[8] Denning, S. 2010. What HBR won't say: Why BPR failed. Retrieved from: http://stevedenning.typepad.com/steve_denning/2010/07/what-hbr-wont-say-why-bpr-failed.html. Accessed on 14 March 2012.

[9] Business Dictionary. Organizational politics. Retrieved from: http: / / www.businessdictionary.com/definition/organizational-politics.html. Accessed on 4 October 2012.

[10] Cox, J.F., Schleier \& J.G. 2010. Theory of constraints handbook. New York: McGraw Hill.

[11] Furterer, S.L. 2009. Lean six sigma in service. New York: CRC Press.

[12] George, M.L. 2003. Lean six sigma for service. New York: McGraw Hill.

[13] Reijers, H.A, \& S Liman Mansar. 2004. "Best Practices in Business Process Redesign: An Overview and Qualitative Evaluation of Successful Redesign Heuristics." International Journal of Management Science, 33: pp. 283-306.

[14] Harmon, P. 2007. "Manufacturing and Service Processes." Retrieved from: BPTrends.Com. Accessed April 10, 2012.

[15] Den Hengst, $M \&$ de Vrede, G.J. 2004. "Collaborative business engineering: A decade of lessons from the field". Journal of Management Information Systems, 20: pp. 85 -113

[16] Hammer, J.C. 1994. Reengineering the corporation: A manifesto for business revolution. London: Harper Business.

[17] Murphy, J.D. 2009. Flawless execution: Bridging the continuous improvement gap. Retrieved from: http: / / www.articlesbase.com/management-articles/flawless-execution-bridging-the-continuousimprovement-gap-878195.html. Accessed on 15 March 2012.

[18] Nave, D. 2002. How to compare six sigma, lean and theory of constraints. Quality Progress, 73-78

[19] Mayer, R.S \& de Witte, P.S. 1999. Delivering results: Evolving BPR from art to engineering. Massachusetts: Kluwer Academic Publishers.

[20] Rock, N.L. 2003. Examining the relationship between business process reengineering and information technology. Maryland: Bowie State University.

[21] Muthu, S., Whitman, L., \& Hossein Cheraghi, S. 1999. "Business Process Engineering: A Consolidated Methodology." San Antonio, Texas: Wichita State University.

[22] Grover, V., Seong, J. R., Kettinger, W. J. \& Teng, J. T. 1995. "The Implementation of Business Process Reengineering". Journal of Management Information Systems, 12(1), pp. 109-144.

[23] Ragin, C.C. 2008. Redesigning social enquiry fuzzy sets and beyond. Chicago: The University of Chicago Press. 